\title{
Fine Root Traits of Pinus koraiensis Varied with Soil Cation Exchange Capacity in Natural Forests
}

\author{
Shuxia Jia ${ }^{1,2} \mathbb{D}$, Xingpeng Li $^{1, *}$, Wensheng Sun ${ }^{3}$, Qian Wang ${ }^{2}$, Hongwen Liu ${ }^{2}$, Chunyan Zhou ${ }^{4}$, Weina Zhang ${ }^{4}$ \\ and Feng $\mathrm{Li}^{4}$ \\ 1 College of Forestry, Beihua University, Jilin 132013, China; jiashuxia@iga.ac.cn \\ 2 Key Laboratory of Mollisols Agroecology, Northeast Institute of Geography and Agroecology, \\ Chinese Academy of Sciences, Changchun 130102, China; wangqian184@mails.ucas.ac.cn (Q.W.); \\ liuhongwen@iga.ac.cn (H.L.) \\ 3 Jilin Provincial Academy of Forestry Sciences, Changchun 130033, China; sunwensheng@126.com \\ 4 Lushuihe Forestry Bureau of Jilin Province, Fusong 134506, China; zhouchunyan2021@126.com (C.Z.); \\ zwn5690@163.com (W.Z.); lifeng20210322@163.com (F.L.) \\ * Correspondence: xingpengli@beihua.edu.cn
}

check for updates

Citation: Jia, S.; Li, X.; Sun, W.; Wang, Q.; Liu, H.; Zhou, C.; Zhang, W.; Li, F. Fine Root Traits of Pinus koraiensis Varied with Soil Cation Exchange Capacity in Natural Forests. Land 2021, 10, 363. https://doi.org/ $10.3390 /$ land 10040363

Academic Editor: Bruno Marino

Received: 19 February 2021

Accepted: 17 March 2021

Published: 1 April 2021

Publisher's Note: MDPI stays neutral with regard to jurisdictional claims in published maps and institutional affiliations.

Copyright: (c) 2021 by the authors. Licensee MDPI, Basel, Switzerland. This article is an open access article distributed under the terms and conditions of the Creative Commons Attribution (CC BY) license (https:// creativecommons.org/licenses/by/ $4.0 /)$.

\begin{abstract}
Adaptation of fine root plasticity to soil nutrients heterogeneity in natural forest ecosystems has not been well explored. The study aimed to determine seasonal variations of fine root traits in Pinus koraiensis natural forests and explore the relationship between fine root traits and soil properties. Root and soil samples were collected from the coniferous broad-leaved mixed forest (BP), monospecific $P$. koraiensis forest (MP), and coniferous mixed forest (CP). Soil available phosphorus (P) content for MP was 31.7\% and 39.8\% lower than for BP and CP. Soil cation exchange capacity (CEC) for MP was lower by $23.5 \%$ and $27.2 \%$ than for BP and CP, respectively. In July, specific root lengths and root surface areas for $\mathrm{BP}$ and $\mathrm{CP}$ (mixed forests) were significantly higher than for MP (monospecific forest). A structural equation model showed that CEC had a significant effect on fine root traits. Root diameter, root volume density, and root surface area density were negatively correlated with CEC. Fine root traits plasticity of $P$. koraiensis are closely related to soil available nutrient contents, CEC, and species composition at the ecosystem level.
\end{abstract}

Keywords: fine root traits plasticity; specific root length; soil properties; soil cation exchange capacity; species composition

\section{Introduction}

Fine roots (diameter $\leq 2 \mathrm{~mm}$ ) play an essential role in the biogeochemical cycle of forest ecosystems. Fine roots constitute $2-5 \%$ of total forest biomass [1], 22-32\% of annual net primary productivity of forest ecosystems [2], and 50-70\% of soil carbon [3]. The dynamics of fine roots (morphology, biomass, turnover rate, etc.) are modulated by various abiotic and biological factors, such as soil properties, tree species, and stand type [4]. Understanding the patterns of fine root traits for resource exploitation and whether they vary with soil properties is believed to produce positive effects on mature stand stability.

Fine roots mainly play a role in obtaining soil resources (water and nutrients) by changing morphological characteristics, production, and turnover [5,6]; therefore, soil properties determine fine root distribution [7]. For example, a significant relationship has been reported between soil resource availability and root trait distribution [8]. An increase in specific root length (SRL) of first-order root (order-based classification) results in faster growth of roots due to an increase in soil resource spatial and temporal availability [9]. High SRL improves resource foraging efficiency [10,11]. In secondary forest and plantation, fine root biomass decreases under sufficient soil nutrient conditions [11]. Fine root traits also vary with forms of nutrients in soil solution, such as nitrate acquisition is referred to as 'steep, cheap, and deep' by mass flow, and phosphate acquisition is referred to as 'topsoil 
foraging' [12] by diffusion. Moreover, the variations of fine root traits are reported globally and are correlated with climate conditions [7]. Previous studies report that SRL is negatively and positively associated with soil fertility $[13,14]$, which is negatively correlated with soil bulk density $[15,16]$. While SRL is not correlated with soil cation exchange capacity (CEC) and soil $\mathrm{pH}$ variations [7]. CEC is positively correlated with fine-root tissue density (RTD), and 3\% RTD variation is attributed to CEC. Soil pH is negatively correlated with RTD, and $4 \%$ variation is attributed to soil $\mathrm{pH}$ [7]. In addition, high trait variations are associated with most soil conditions such as soil depth, soil temperature, and water content (mainly seasonal variations) for wide-ranging resource economics strategies $[17,18]$. However, how and to what extent soil properties drive the root trait and function variations is still unclear, limiting our ability to estimate nutrient acquisition strategies of plants and stand stability and productivity in mixed forests.

The distribution of plant root traits is also affected by specific species, growth dynamics, and the presence or absence of other species [8]. Fine root traits respond to tree ontogenetic stage with conflicting results, such as lower SRL of Pinus sylvestris in the mature stage than in younger stages, while stable SRL of Picea abies between two stages. Fine root diameters $(<2 \mathrm{~mm})$ were generally thicker with the increasing tree age [19]. Root morphological traits (such as fine root diameter) were highly conserved across species [20]. In general, fine roots are thicker with lower SRL in evergreen conifers than deciduous trees $[19,21]$. Furthermore, the interspecific root competition direction shifted with the increasing stand age [22]. There is a certain synchrony pattern between soil properties peak and the growing season, which results in a compound for root traits and function over the growing season. It is widely believed that mixed forests are more sustainable and productive than pure stands. Vertical stratification of the rooting space occurred for some species to reducing the interspecific below-ground competition in the mixed forest [19]. Therefore, the relationship between root traits and soil properties resulting from the combination of species and vegetation over the growing season would help us better understand the ecosystem functions of fine roots and interspecific competition strategies. The objectives of this study were (1) to determine the differences in roots traits with different coexistence species in P. koraiensis natural forest, (2) to explore seasonal variations of fine root traits in P. koraiensis species, (3) and to explore the relationship between fine root traits and soil physical and chemical properties under $P$. koraiensis natural forest in Northeast China.

\section{Materials and Methods}

\subsection{Study Site}

The study was conducted from a broad-leaved P. koraiensis mixed forest in Changbai Mountain, located at Lushuihe Forestry Bureau $\left(127^{\circ} 29^{\prime}-128^{\circ} 02^{\prime} \mathrm{E}, 42^{\circ} 20^{\prime}-42^{\circ} 40^{\prime} \mathrm{N}\right)$ in Fusong County of Jilin Province, China. The climate for the area is temperate continental with a long cold winter and short cool summer. The region's annual mean temperature is $3.5^{\circ} \mathrm{C}$, annual mean precipitation is $800-1040 \mathrm{~mm}$ with more than $70-80 \%$ occurring from June to September. The soil of the research fields was brown forest soil with an average depth of $50 \mathrm{~cm}$. Details on soil characteristics of the study site are shown in Table 1 . The study site's dominant tree species were P. koraiensis, Tilia amurensis, Quercus mongolica, Picea koraiensis, Acer truncatum, Fraxinus mandshurica, Ulmus japonica, Betula platyphylla, Juglans mandshurica, and Phellodendron amurense. 
Table 1. The basic stand situation and soil properties in three forest types.

\begin{tabular}{|c|c|c|c|}
\hline Forest Type & $\begin{array}{l}\text { Broadleaf Mixed } \\
\text { Forest (BP) }\end{array}$ & $\begin{array}{l}\text { P. koraiensis } \\
\text { Forest (MP) }\end{array}$ & $\begin{array}{l}\text { Coniferous } \\
\text { Forest (CP) }\end{array}$ \\
\hline Stand density (plants $\cdot \mathrm{hm}^{-2}$ ) & $450 \pm 5 a$ & $350 \pm 6 b$ & $550 \pm 3 c$ \\
\hline Tree height $(\mathrm{m})$ & $25.3 \pm 0.4 \mathrm{a}$ & $23.5 \pm 0.3 \mathrm{a}$ & $22.7 \pm 0.2 \mathrm{ab}$ \\
\hline $\mathrm{DHB}(\mathrm{cm})$ & $48.4 \pm 0.2 \mathrm{a}$ & $48.5 \pm 0.3 \mathrm{a}$ & $44.6 \pm 0.4 b$ \\
\hline Soil sand (\%) & $0.59 \pm 0.04 \mathrm{a}$ & $0.34 \pm 0.13 \mathrm{a}$ & $0.55 \pm 0.16 \mathrm{a}$ \\
\hline Soil silt (\%) & $63.30 \pm 6.30 \mathrm{a}$ & $62.01 \pm 6.75 \mathrm{a}$ & $63.93 \pm 2.80 \mathrm{a}$ \\
\hline Soil clay (\%) & $36.11 \pm 6.30 \mathrm{a}$ & $37.66 \pm 6.79 \mathrm{a}$ & $35.53 \pm 2.69 \mathrm{a}$ \\
\hline Soil total $\mathrm{N}\left(\mathrm{g} \cdot \mathrm{kg}^{-1}\right)$ & $7.61 \pm 0.04 \mathrm{a}$ & $7.42 \pm 0.54 \mathrm{a}$ & $7.13 \pm 0.38 \mathrm{a}$ \\
\hline Soil total P $\left(\mathrm{g} \cdot \mathrm{kg}^{-1}\right)$ & $1.35 \pm 0.09 \mathrm{a}$ & $0.98 \pm 0.03 b$ & $1.44 \pm 0.08 \mathrm{a}$ \\
\hline Soil total $\mathrm{K}\left(\mathrm{g} \cdot \mathrm{kg}^{-1}\right)$ & $15.62 \pm 0.26 \mathrm{a}$ & $16.31 \pm 0.70 \mathrm{a}$ & $15.52 \pm 0.47 \mathrm{a}$ \\
\hline Soil $\mathrm{pH}$ & $5.32 \pm 0.12 \mathrm{a}$ & $4.91 \pm 0.07 \mathrm{~b}$ & $5.18 \pm 0.06 \mathrm{a}$ \\
\hline $\mathrm{CEC}\left(\mathrm{cmol} \cdot \mathrm{kg}^{-1}\right)$ & $53.56 \pm 1.14 \mathrm{a}$ & $38.74 \pm 3.06 b$ & $50.64 \pm 0.86 \mathrm{a}$ \\
\hline Soil alkalotic $\mathrm{N}\left(\mathrm{mg} \cdot \mathrm{kg}^{-1}\right)$ & $810.88 \pm 9.67 \mathrm{a}$ & $565.04 \pm 7.01 \mathrm{~b}$ & $856.80 \pm 34.97 \mathrm{a}$ \\
\hline Soil available $\mathrm{P}\left(\mathrm{mg} \cdot \mathrm{kg}^{-1}\right)$ & $25.69 \pm 2.99 \mathrm{a}$ & $17.53 \pm 1.03 \mathrm{~b}$ & $29.13 \pm 2.49 \mathrm{a}$ \\
\hline Soil available $\mathrm{K}\left(\mathrm{mg} \cdot \mathrm{kg}^{-1}\right)$ & $183.32 \pm 14.49 \mathrm{a}$ & $165.08 \pm 5.83 \mathrm{a}$ & $159.19 \pm 10.10 \mathrm{a}$ \\
\hline Soil bulk density $\left(\mathrm{g} \cdot \mathrm{cm}^{-3}\right)$ & $0.62 \pm 0.03 \mathrm{a}$ & $0.65 \pm 0.02 \mathrm{a}$ & $0.62 \pm 0.02 \mathrm{a}$ \\
\hline Soil infiltration rate $\left(10^{-3} \mathrm{~cm} \cdot \mathrm{s}^{-1}\right)$ & $12.75 \pm 1.32 \mathrm{a}$ & $8.81 \pm 0.56 b$ & $9.41 \pm 1.45 \mathrm{ab}$ \\
\hline
\end{tabular}

Note: Different lowercase letters at the same row indicate the significant difference among forest types at 0.05 level.

\subsection{Experimental Design}

Three natural forests in Dongsheng forest farm were selected for this study in September 2017. Selected forests were broad-leaved P. koraiensis mixed forest (BP, P. koraiensis: T. amurensis: F. mandshurica: Q. mongolica: A. truncatum $\left.=5: 1: 1: 1: 1,127^{\circ} 53^{\prime} 6^{\prime \prime} \mathrm{E}, 42^{\circ} 26^{\prime} 53^{\prime \prime} \mathrm{N}\right)$, monospecific $P$. koraiensis forest (MP, P. koraiensis: T. amurensis $=9: 1,127^{\circ} 53^{\prime} 29^{\prime \prime} \mathrm{E}, 42^{\circ} 26^{\prime} 41^{\prime \prime} \mathrm{N}$ ) and coniferous $P$. koraiensis mixed forest $(\mathrm{CP}, P$. koraiensis: P. koraiensis (spruce): T. amurensis: Q. mongolica $\left.=6: 1: 2: 1,127^{\circ} 54^{\prime} 27^{\prime \prime} \mathrm{E}, 42^{\circ} 25^{\prime} 41^{\prime \prime} \mathrm{N}\right)$. Three $20 \times 20 \mathrm{~m}$ plots were randomly established for each forest type. The average stand age (P. koraiensis) was 170, 175, and 165 for BP, MP, and CP. The canopy closure was more than 0.7 , the slopes of the site were the same in all three forest types. Details of stand information are shown in Table 1.

\subsection{Sampling}

Three soil samples of $20 \times 20 \times 10 \mathrm{~cm}$ in volume were collected from each plot for root and soil analysis in May, July, and September of 2018. Soils were sampled at approximately 1-2 $\mathrm{m}$ from P. koraiensis and within $3 \mathrm{~m}$ distance around T. amurensis and/or P. koraiensis (spruce).

\subsection{Root Traits Measurement}

Roots were picked based on the shape and color of P. koraiensis, then were washed and stored at $4{ }^{\circ} \mathrm{C}$ for analysis of traits. Diameter $(\mathrm{mm})$, length $(\mathrm{cm})$, surface area $\left(\mathrm{cm}^{2}\right)$, and volume $\left(\mathrm{cm}^{3}\right)$ of roots were determined by scanning roots, and data were analyzed with WinRhizo Pro software (Regent Instruments, Quebec, ON, Canada). All root samples were then dried at $65^{\circ} \mathrm{C}$ to constant mass (at least $48 \mathrm{~h}$ ) and weighed. Fine root (diameter $\leq 2 \mathrm{~mm}$ ) length density (RLD), root surface area density (RAD), and root volume density (RVD) of $P$. koraiensis were calculated by dividing total fine root length, surface area, and volume, respectively by soil sampling volume $\left(20 \times 20 \times 10 \mathrm{~cm}^{3}\right)$. Specific root length $(\mathrm{SRL})(\mathrm{m} / \mathrm{g})$ and specific root surface area (SRA) $\left(\mathrm{cm}^{2} / \mathrm{g}\right)$ were calculated by dividing the total root length and surface area of $P$. koraiensis fine roots by the dry weight.

\subsection{Soil Properties Measurement}

Six cylindrical soil cores $\left(100 \mathrm{~cm}^{3}\right)$ were collected before root and soil sampling from an undisturbed area for soil bulk density and infiltration rate analysis. The fresh weight of soil cylindrical cores was determined. Infiltration rate was then measured using a tst-55 
permeameter, and soil samples were dried at $105^{\circ} \mathrm{C}$ for $24 \mathrm{~h}$ to determine bulk density. Soil total nitrogen $(\mathrm{N})$ was determined using the Kjeldahl procedure [23]. For soil total phosphorus $(\mathrm{P})$ and total potassium $(\mathrm{K})$, soils were digested with concentrated $\mathrm{HNO}_{3} / \mathrm{HClO}_{4} / \mathrm{HF}$, soil available $\mathrm{P}$ was extracted with $\mathrm{HCL} / \mathrm{HSO}_{4}\left(0.05 \mathrm{molL}^{-1} / 0.025 \mathrm{molL}{ }^{-1}\right)$, soil available $\mathrm{K}$ was extracted with $\mathrm{CH}_{3} \mathrm{COONH}_{4}$, then total $\mathrm{P}, \mathrm{K}$, available $\mathrm{P}, \mathrm{K}$ was determined using inductive coupled plasma-atomic emission spectrometry (ICP-AES, ICPS-7500, Shimadzu, Kyoto, Japan) [24]. Soil available $\mathrm{N}$ was determined by the Alkaline hydrolysis diffusion method [23]. Soil cation exchange capacity (CEC) was determined using the pH 7.0 ammonium acetate procedure [23]. Soil $\mathrm{pH}$ was measured in a 1:2.5 (soil: water) suspension using a glass electrode (Sartorius PB-10). Soil particle size distribution (texture) was determined through the pipette method by removing organic matter, carbonates, and oxides using $\mathrm{H}_{2} \mathrm{O}_{2}$ and hydrochloric acid, and dispersion was carried out using sodium hexametaphosphate [23].

\subsection{Data Analysis}

Soil properties and root traits parameters were $\ln (x+1)$ transformed to increase normality prior to statistical analysis. Effect of forest type on soil physical and chemical properties (soil bulk density, infiltration rate, total $\mathrm{P}, \mathrm{N}, \mathrm{K}$ content and available $\mathrm{P}, \mathrm{N}, \mathrm{K}$ content, soil particle size distribution, soil $\mathrm{pH}$ ) was analyzed using one-way analysis of variance (ANOVA). The effect of forest type and sampling time on root traits (SRL, SRA, RLD, RAD, and RVD) was analyzed using the general linear model. Multiple comparisons tests to determine differences across forest types were conducted using the least significant difference (LSD, $\alpha=0.05$ ). All analyses were performed using SPSS software (version 16.0, SPSS Inc., Chicago, IL, USA).

Structural equation modeling (SEM) was used to analyze soil properties' impact on fine root traits of different forest types. We hypothesized that differences in soil properties under different forest types were the main factors affecting fine root traits and biomass. The initial model included six soil factors (soil total $\mathrm{P}$, available $\mathrm{P}$, soil available $\mathrm{N}, \mathrm{pH}$, infiltration rate, and CEC) and seven fine root trait variables (Diameter, SRL, SRA, RLD, RAD, RVD, and fine root biomass). The results showed the significant paths for correlated parameters. Mardia's test was used to estimate the multivariate normality of the dataset, and the model fit was assessed using $\chi^{2}$-test, comparative fit index (CFI), and root mean square error of approximation (RMSEA). The analysis was performed with SPSS AMOS 21.0 software (SPSS Inc., Hong Kong) using the "robust" maximum likelihood estimation procedures.

\section{Results}

\subsection{Soil Properties}

Soil particle size distribution (sand, silt, and clay content), total $\mathrm{N}$, total $\mathrm{K}$, and available K content were not significantly different among the three forest types (Table 1). Soil total P content in monospecific P. koraiensis forest (MP) was significantly lower by $27.3 \%$ and $31.7 \%$ than broad-leaved P. koraiensis mixed forest (BP) and coniferous P. koraiensis mixed forest (CP), respectively. Soil available P content of MP was significantly lower by $31.7 \%(\mathrm{BP})$ and $39.8 \%(\mathrm{CP})$; whereas soil available $\mathrm{N}$ content of MP was significantly lower by $30.3 \%(\mathrm{BP})$ and $34.1 \%(\mathrm{CP})$, respectively (Table 1$)$. Soil infiltration rate under MP was $30.8 \%$ lower than for BP, whereas CEC for MP was significantly lower by $23.5 \%$ and $27.2 \%$ than for $\mathrm{CP}$ and $\mathrm{BP}$.

\subsection{Fine Roots Biomass}

Fine root biomass showed significant seasonal variations and varied with forest type $(p<0.05)$ (Figure 1, Table 2). The highest biomass in September was 1.9, 1.4, and 1.6 times those in May for BP, MP, and CP, respectively (Figure 1). During the growing season, the average root biomass under BP was lower by $31.2 \%$ and $43.4 \%$ than that under MP and CP. 

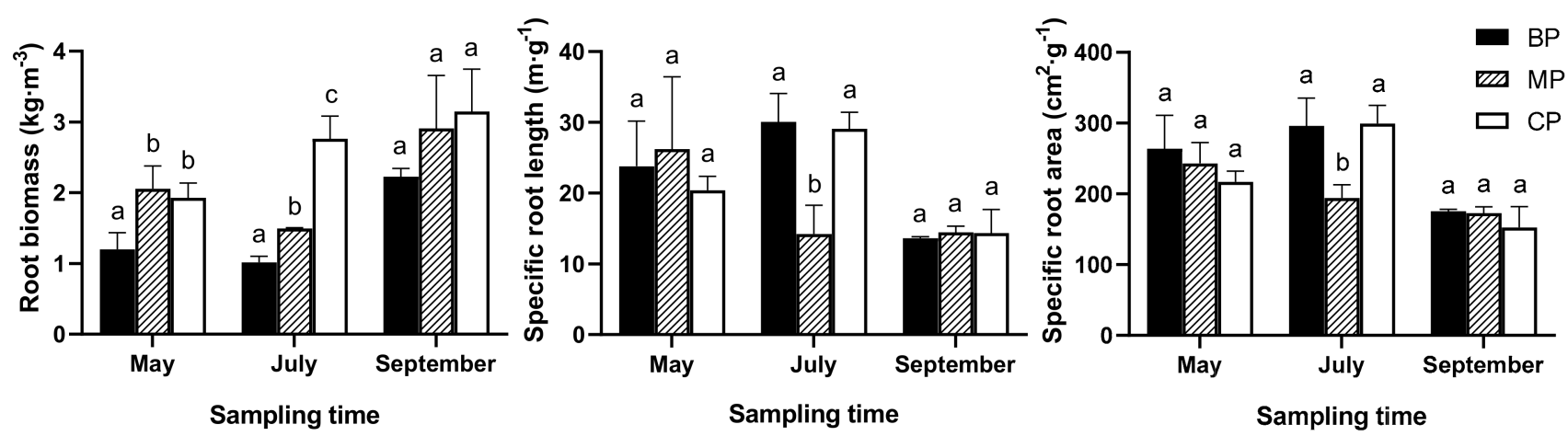

Figure 1. Root biomass, specific root length, and surface area of different sampling time under three forest types. Different lowercase letters indicate significant difference among forest types at 0.05 level, as below.

Table 2. Analysis of variance (ANOVA) results of the effects of forest type and sampling time on fine root traits.

\begin{tabular}{|c|c|c|c|c|c|}
\hline Source & Dependent Variable & df & Mean Square & $\mathbf{F}$ & Sig. \\
\hline \multirow{10}{*}{$\begin{array}{c}\text { Sampling } \\
\text { time }(S)\end{array}$} & Root diameter (cm) & 2 & 0.001 & 0.512 & 0.608 \\
\hline & Specific root length $\left(\mathrm{m} \cdot \mathrm{g}-{ }^{1}\right)$ & 2 & 0.115 & 6.479 & 0.008 \\
\hline & Specific root area $\left(\mathrm{cm}^{2} \cdot \mathrm{g}^{-1}\right)$ & 2 & 0.093 & 11.828 & 0.001 \\
\hline & Root tissue density $\left(\mathrm{g} \cdot \mathrm{cm}^{-3}\right)$ & 2 & 0.003 & 7.739 & 0.004 \\
\hline & Root length density $\left(\mathrm{cm} \cdot \mathrm{cm}^{-3}\right)$ & 2 & 0.003 & 1.040 & 0.374 \\
\hline & Root area density $\left(\mathrm{m}^{2} \cdot \mathrm{m}^{-3}\right)$ & 2 & 0.013 & 2.066 & 0.156 \\
\hline & Root volume density $\left(\mathrm{mm}^{3} \cdot \mathrm{cm}^{-3}\right)$ & 2 & 0.026 & 3.014 & 0.074 \\
\hline & Root biomass $\left(\mathrm{kg} \cdot \mathrm{m}^{-3}\right)$ & 2 & 0.123 & 13.274 & 0.001 \\
\hline & Root diameter $(\mathrm{cm})$ & 2 & 0.001 & 0.897 & 0.425 \\
\hline & Specific root length $\left(\mathrm{m} \cdot \mathrm{g}^{-1}\right)$ & 2 & 0.054 & 3.013 & 0.074 \\
\hline \multirow{7}{*}{$\begin{array}{l}\text { Forest type } \\
\text { (F) }\end{array}$} & Specific root area $\left(\mathrm{cm}^{2} \cdot \mathrm{g}^{-1}\right)$ & 2 & 0.033 & 4.253 & 0.031 \\
\hline & Root tissue density $\left(\mathrm{g} \cdot \mathrm{cm}^{-3}\right)$ & 2 & 0.001 & 2.359 & 0.123 \\
\hline & Root length density $\left(\mathrm{cm} \cdot \mathrm{cm}^{-3}\right)$ & 2 & 0.062 & 23.690 & $<0.001$ \\
\hline & Root area density $\left(\mathrm{m}^{2} \cdot \mathrm{m}^{-3}\right)$ & 2 & 0.072 & 11.377 & 0.001 \\
\hline & Root volume density $\left(\mathrm{mm}^{3} \cdot \mathrm{cm}^{-3}\right)$ & 2 & 0.031 & 3.629 & 0.047 \\
\hline & Root biomass $\left(\mathrm{kg} \cdot \mathrm{m}^{-3}\right)$ & 2 & 0.159 & 6.201 & 0.009 \\
\hline & Root diameter $(\mathrm{cm})$ & 4 & 0.001 & 2.176 & 0.113 \\
\hline \multirow[t]{7}{*}{$\mathrm{S} \times \mathrm{F}$} & Specific root length $\left(\mathrm{m} \cdot \mathrm{g}^{-1}\right)$ & 4 & 0.030 & 1.684 & 0.197 \\
\hline & Specific root area $\left(\mathrm{cm}^{2} \cdot \mathrm{g}^{-1}\right)$ & 4 & 0.005 & 0.633 & 0.646 \\
\hline & Root tissue density $\left(\mathrm{g} \cdot \mathrm{cm}^{-3}\right)$ & 4 & 0.001 & 1.378 & 0.281 \\
\hline & Root length density $\left(\mathrm{cm} \cdot \mathrm{cm}^{-3}\right)$ & 4 & 0.006 & 2.418 & 0.086 \\
\hline & Root area density $\left(\mathrm{m}^{2} \cdot \mathrm{m}^{-3}\right)$ & 4 & 0.009 & 1.371 & 0.283 \\
\hline & Root volume density $\left(\mathrm{mm}^{3} \cdot \mathrm{cm}^{-3}\right)$ & 4 & 0.039 & 4.503 & 0.011 \\
\hline & Root biomass $\left(\mathrm{kg} \cdot \mathrm{m}^{-3}\right)$ & 4 & 0.017 & 0.920 & 0.474 \\
\hline
\end{tabular}

\subsection{Specific Root Length (SRL) and Specific Root Surface Area (SRA)}

Effects of forest type on SRL and SRA varied with sampling time (Figure 1). SRL for MP in July was significantly lower by $52.7 .6 \%$ and $51.2 \%$ compared with SRL for BP and $\mathrm{CP}$, respectively. In addition, SRA for MP in July was significantly lower by $34.5 \%$ and $35.2 \%$ compared with SRA for BP and CP, respectively (Figure 1)

\subsection{Root Morphological Characteristics}

Interaction between forest type and sampling time showed a significant effect on RVD $(p<0.05)$. In May, RVD for MP was significantly lower by $16.4 \%$ and $43.0 \%$ lower than that of $\mathrm{BP}$ and $\mathrm{CP}$, respectively, whereas in July, RVD of MP was 2.7 times more than that of BP (Figure 2). RLD and RAD significantly varied with forest type $(p<0.05)$. The average RLD for MP was significantly higher by $50.0 \%$ compared with that for BP $(p<0.05)$ during the growing season (except for RLD for MP in July), whereas the average RLD for CP was 
$54.6 \%$ higher compared with that for BP (Figure 2). In July and September, RAD for MP was $69.1 \%$ and $39.7 \%$ higher than BP. In addition, RAD for CP was significantly higher by $62.7 \%$ (May), $41.1 \%$ (July), and 30.6\% (September) than that for BP, respectively (Figure 2).
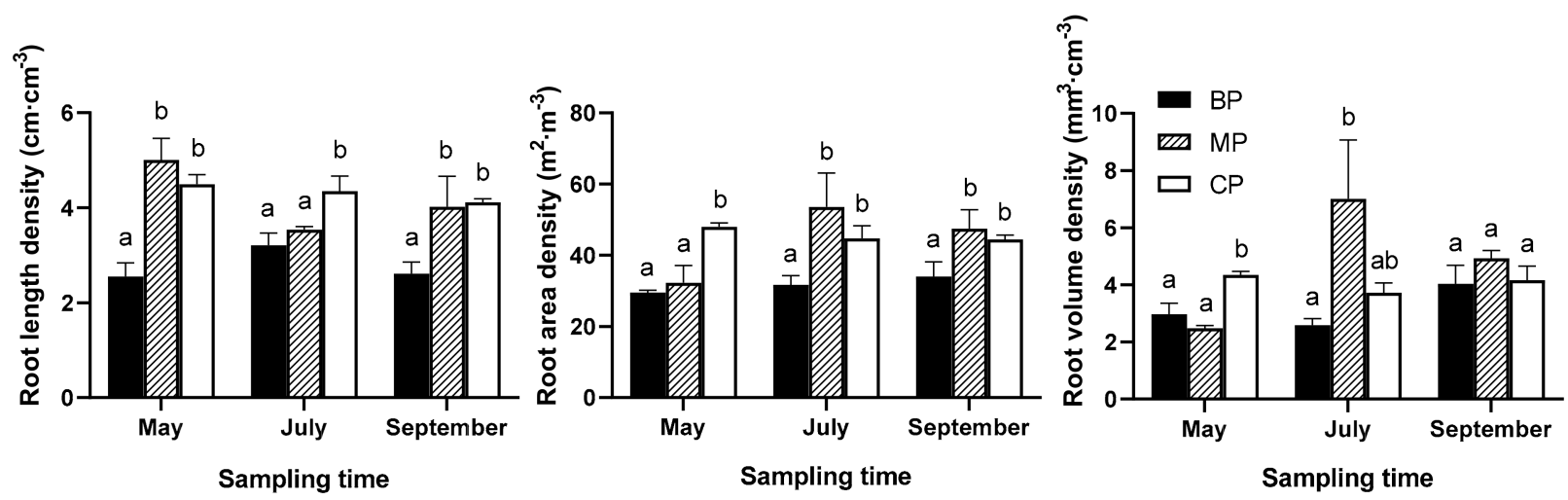

Figure 2. Fine root morphological characteristics per soil volume.

\subsection{Effects of Soil Properties on Fine Root Traits}

SEM revealed that CEC has a significantly higher effect on fine root traits than other factors (Figure 3). Root diameter, RVD, and RAD were negatively correlated with CEC, whereas root diameter and RAD were positively correlated with fine root biomass. SRA was positively correlated with soil total and available P content. Forest type modulated fine root biomass through CEC (Figure 3).

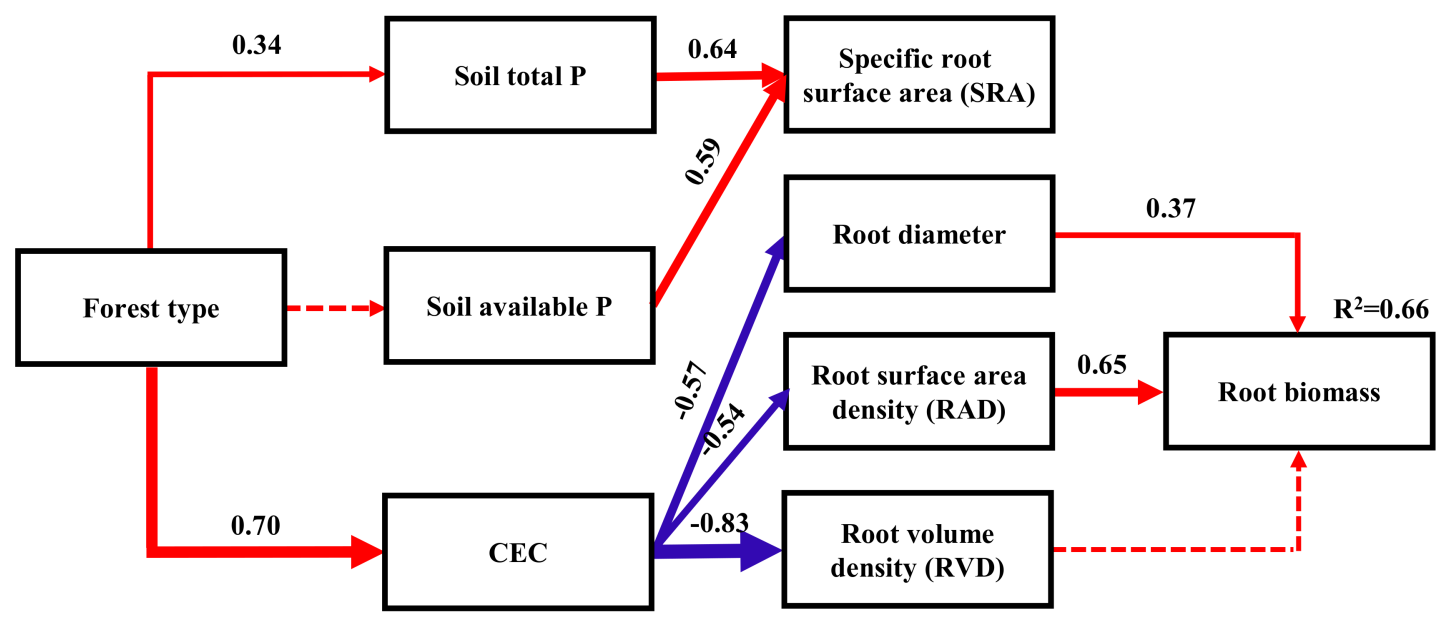

Figure 3. Structural equation model relating forest type effect on fine root traits $(\chi 2=72.16 ; \mathrm{df}=11 ; p=0.475$; comparative fit index $(\mathrm{CFI})=1.000$; root mean square error of approximation $($ RMSEA $)=0.000)$. Rectangles represent observed variables; arrow thickness represents the magnitude of the path coefficient. Solid line arrows represent significant paths $(p<0.05)$, dashed lines represent non-significant paths $(p>0.05)$. Red lines represent the positive paths, and blue lines represent the negative paths.

\section{Discussion}

\subsection{Stand Types}

Complementary resource exploitation is believed to reduce competition but increase stability and productivity by different aboveground (such as tree height, crown form) and below-ground (rooting depth, morphology) traits in mixed forests [22]. Root trait plasticity is more dependent on competitive ability and individual fitness of species, hence community dynamics $[25,26]$, which show adaptation of root to biological and abiotic factors $[27,28]$. Plants maximize the acquisition of immobile nutrients such as $\mathrm{P}$ by increasing 
root hair density and through prolific root branching [28]. Therefore, higher RTD (data not shown), RVD, and RLD (May and September) observed for MP associated with lower soil available $P$ content were adaptations to meet $P$ requirements (Figure 2), concerning the higher competitiveness and foraging capacity. These differences in fine root traits among forest stands can be attributed to responses resulting from reduced resource competition among species and maximizing species coexistence $[29,30]$. The distribution of a root system is also affected by other species [8]. For example, $17 \%$ of root morphological trait variation is attributed to the effect of species combination [8]. Responses of species to neighboring roots (plasticity) may occur to avoid trait overlap. We did not measure the impact of adjacent species on the fine root of $P$. koraiensis, but the higher RTD, RVD, and RLD under MP may be related to the lower stand density in the monospecific forest. Our findings imply that the diversity of root traits modulates species coexistence, thus promoting community stability in complex forest ecosystems. Therefore, further studies should explore the role of root interaction in regulating species coexistence and system function.

In addition, plant-fungal associations with arbuscular mycorrhizal and ectomycorrhizal fungi are correlated with the nutrient economy in forest ecosystems [31,32], especially low solubility and the mobility of $\mathrm{P}$ sources. For instance, the nutrient-acquisition strategy called "scavenging" involves access to nutrients through a symbiotic relationship with mycorrhizal fungi [33]. Degree and type of mycorrhizal infection across species affect root traits [32]. Higher SRL usually results in lower mycorrhizal dependence [34,35] and faster root tissue turnover [36]. Previous studies report that the mycorrhizal infection rate of P. koraiensis in broad-leaved mixed forest decreased by 15\% compared with the rate in monospecific P. koraiensis forest [37]. Higher SRL and SRA observed in BP compared with other forests can be attributed to differences in mycorrhizal infection rate (Figure 1), or the increasing resource exploitation efficiency of $P$. koraiensis with resource depletion of the competing species [38]. The fine roots increased soil exploration or exploitation efficiency (nutrient economy) resulting in reduced root life span $[39,40]$ and increased mycorrhizal infection rate. These findings implied that the foraging strategy of fine roots in broad-leaved P. koraiensis mixed forest is more intensive and depends on the root-mycorrhiza-bacteria continuum (acquisitive resource economics strategy). Moreover, roots in a monospecific $P$. koraiensis forest seem to be more extensive with greater $\mathrm{C}$ allocation to root formation.

\subsection{Seasonal Variations}

Root trait plasticity is significantly correlated with heterogeneous distributions of soil nutrients and water [36]. In addition, root traits are significantly affected by endogenous factors (species, root exudates, mycorrhizal associations types, etc.), and exogenous factors, such as plant phenology and soil properties [41]. These findings explain why root traits showed significant seasonal variations both at an individual level (fine root morphology) and at the community level (root biomass and volume), positively correlated with plant phenology. In July, SRL was higher than that in September $(p<0.05)$ (Figure 1). The phenology of fine roots almost overlapped with seasonal variations of aboveground organs and root vascular cambium [42]. Higher soil temperature in summer promotes fine roots growth, especially the growth of cambium to provide nutrients and water transport for plants through the increased xylem [43]. Photosynthesis products are stored in fine roots as starch for growth when the soil temperature is low in autumn [43]. This results in a higher fall peak of root biomass both in P. koraiensis (Figure 1) and Q. ilex stands [42].

\subsection{Relationship between Root Traits and Soil Properties}

Interactions between roots and soil are complementary [12], plant roots affect soil formation and structural stability through physical, chemical, and biological processes $[12,36,44]$. On the other hand, highly heterogeneous patches of soil properties promote the placement and activity of plant roots [12,45]. Furthermore, fine roots facilitate plant development by adapting to the changing environments (soil water content, nutrient availability, and soil physical properties) [18]. For example, fine roots distribution 
in soil depends greatly on soil resources availability (N addition) [5]. Resource acquisition efficiency is improved by increasing individual root growth when soil nutrients are insufficient [10]. However, resource acquisition efficiency is enhanced by decreasing root biomass when soil nutrients are sufficient [11]. Our study's findings showed that fine root biomass in July in monospecific $P$. koraiensis forest with lower soil available nutrients (Table 1) was $36.5 \%$ higher than that for coniferous and broad-leaved mixed forest due to higher available nutrient content. This finding indicates that $P$. koraiensis adapts to environmental changes by optimizing fine root biomass to increase uptake of nutrients. Lower biomass investments, higher root cost efficiency, and faster growth indicate that these roots are acquisitive or intensive when accessing resources [32,46].

However, different root traits have a higher effect on the simultaneous acquisition of different resources due to the heterogeneity of these resources [32]. Plants exhibit various adaptation strategies by changing fine root traits, such as root diameter and living root surface area [6,11]. Positive correlations between SRA and soil total and available P content (Figure 3) imply that fine roots absorption capacity increases with an increase in the soil available $\mathrm{P}$ content. This can be attributed to the ability of plants to modify cortex ionabsorption and stele water-transport functions based on the supply of the most limited resource supply to adapt to changing environmental conditions [47]. Soils with larger CEC and high base saturation levels are referred to as good soils to support better vegetation growth. In addition, CEC is a key abiotic determinant for plant species distribution [48]. This can be attributed to the negative correlation between CEC and fine root traits (Root diameter, RVD, RAD) among different stands (Figure 3). This relationship implies that roots are more resource-conservative in highly fertile conditions. Therefore, plants preferentially allocate more biomass to fine roots under soil nutrients deficiency, which is consistent with reports from previous studies on increasing root absorptive areas in $\mathrm{N}$-limited forests [46]. Soil chemical (soil $\mathrm{pH}$ ) properties affect root traits and functions implying that roots are not always optimally adjusted to soil resources. A lower $\mathrm{pH}$ (range from 4.5 to 7.8 ) is correlated with lower nutrient mobility in soil solution [7]. Unfortunately, the study did not fully explore the effect of soil $\mathrm{pH}$ on root traits. Lower soil $\mathrm{pH}$ in monospecific $P$. koraiensis forest may have limited nutrient mobility especially $\mathrm{P}$ content in soil solution, resulting in low soil available phosphorus content in this stand. Plants showed significant effects on the rhizosphere microbial community [49], on the amount and composition of root exudates (primary metabolites such as sugars, amino acids, and organic acids) and phenolic root profiles (secondary metabolites) were highly species-specific [50]. Therefore, differences in soil available $\mathrm{N}$ and $\mathrm{P}$ contents between mixed and monospecific P. koraiensis forest (Table 1) can be attributed to differences in root exudates among stands. However, the soil environment comprises several components, and root traits varied with the soil environment. Therefore, further studies based on multiple soil resource components (soil resources, structural and chemical characteristics, etc.) should be carried out to explore their effect on root traits, function, and uptake strategies (including the mycorrhizal pathway) across species and in different environments [32,51,52].

\section{Conclusions}

Fine root traits (specific root length, specific root surface area, and fine root biomass) vary with the growing season. In addition, specific root surface area, surface area density, root length density of $P$. koraiensis varies with forest type in natural forests of Northeast China. Fine root traits are positively correlated with soil cation exchange capacity and soil P content. These findings imply that the foraging strategies of fine roots in P. koraiensis are positively correlated with soil environment (nutrient availability, properties) and species coexistence. Specific root length and specific root surface area of $P$. koraiensis increased to improve soil exploitation and sequestration efficiency when co-existed with other species. On the other hand, root formation (biomass and length) increased in monospecific $P$. koraiensis forest to maximize resource acquisition. 
Author Contributions: S.J. and X.L. conceived the ideas and designed the experiments; C.Z., W.Z. and F.L. sampled in the field; H.L. and Q.W. performed the experiments; S.J. and H.L. conducted the data analyses and prepared the manuscript; W.S. offered funding acquisition; X.L. offered constructive guidance. All authors have read and agreed to the published version of the manuscript.

Funding: This research was funded by the National Key R\&D Program of China, grant number 2017YFD0601103, and the National Natural Science Foundation of China, grant number 42071064.

Institutional Review Board Statement: Not applicable.

Informed Consent Statement: Not applicable.

Data Availability Statement: The data presented is primarily reflected in the article, more details are available on request from the corresponding author.

Acknowledgments: We appreciate H.F. Yao, and Q. Wang for their assistance in field sampling. We thank anonymous reviewers and the academic editor for their valuable comments and suggestions.

Conflicts of Interest: The authors declare no conflict of interest.

\section{References}

1. Olesinski, J.; Lavigne, M.B.; Kershaw, J.A.; Krasowski, M.J. Fine-root dynamics change during stand development and in response to thinning in balsam fir (Abies balsamea L. Mill.) forests. For. Ecol. Manag. 2012, 286, 48-58. [CrossRef]

2. Finér, L.; Zverev, V.; Palviainen, M.; Romanis, T.; Kozlov, M.V. Variation in fine root biomass along a $1000 \mathrm{~km}$ long latitudinal climatic gradient in mixed boreal forests of North-East Europe. For. Ecol. Manag. 2019, 432, 649-655. [CrossRef]

3. Clemmensen, K.E.; Bahr, A.; Ovaskainen, O.; Dahlberg, A.; Ekblad, A.; Wallander, H.; Stenlid, J.; Finlay, R.D.; Wardle, D.A.; Lindahl, B.D. Roots and associated fungi drive long-term carbon sequestration in boreal forest. Science 2013, 340, $1615-1618$. [CrossRef] [PubMed]

4. Yuan, Z.Y.; Chen, H.Y.H. Fine root biomass, production, turnover rates, and nutrient contents in boreal forest ecosystems in relation to species, climate, fertility, and stand age: Literature review and metaanalyses. Crit. Rev. Plant. Sci. 2010, $29,204-221$. [CrossRef]

5. Yan, G.; Chen, F.; Zhang, X.; Wang, J.; Han, S.; Xing, Y.; Wang, Q. Spatial and temporal effects of nitrogen addition on root morphology and growth in a boreal forest. Geoderma 2017, 303, 178-187. [CrossRef]

6. Rasse, D.P. Nitrogen deposition and atmospheric $\mathrm{CO}_{2}$ interactions on fine root dynamics in temperate forests: A theoretical model analysis. Glob. Chang. Biol. 2002, 8, 486-503. [CrossRef]

7. Freschet, G.T.; Valverde-Barrantes, O.J.; Tucker, C.M.; Craine, J.M.; McCormack, M.L.; Violle, C.; Fort, F.; Blackwood, C.B.; Urban-Mead, K.R.; Iversen, C.M.; et al. Climate, soil and plant functional types as drivers of global fine-root trait variation. J. Ecol. 2017, 105, 1182-1196. [CrossRef]

8. Valverde-Barrantes, O.J.; Smemo, K.A.; Feinstein, L.M.; Kershner, M.W.; Blackwood, C.B. The distribution of below-ground traits is explained by intrinsic species differences and intraspecific plasticity in response to root neighbours. J. Ecol. 2013, 101, 933-942. [CrossRef]

9. Eissenstat, D.M.; Kucharski, J.M.; Zadworny, M.; Adams, T.S.; Koide, R.T. Linking root traits to nutrient foraging in arbuscular mycorrhizal trees in a temperate forest. New Phytol. 2015, 208, 114-124. [CrossRef]

10. Ostonen, I.; Helmisaari, H.S.; Borken, W.; Tedersoo, L.; Kukumägi, M.; Bahram, M.; Lindroos, A.J.; Nöjd, P.; Uri, V.; Meril, P.; et al. Fine root foraging strategies in Norway spruce forests across a European climate gradient. Glob. Chang. Biol. 2011, 17, 3620-3632. [CrossRef]

11. Wang, G.L.; Fahey, T.J.; Xue, S.; Liu, F. Root morphology and architecture respond to N addition in Pinus tabuliformis, west China. Oecologia 2013, 171, 583-590. [CrossRef] [PubMed]

12. Jin, K.; White, P.J.; Whalley, W.R.; Shen, J.; Shi, L. Shaping an optimal soil by root-soil interaction. Trends Plant. Sci. 2017, 22, 823-829. [CrossRef] [PubMed]

13. Ryser, P.; Eek, L. Consequences of phenotypic plasticity vs. interspecific differences in leaf and root traits for acquisition of aboveground and belowground resources. Am. J. Bot. 2000, 87, 402-411. [CrossRef] [PubMed]

14. Comas, L.H.; Eissenstat, D.M. Linking fine root traits to maximum potential growth rate among 11 mature temperate tree species. Funct. Ecol. 2004, 18, 388-397. [CrossRef]

15. Clark, L.J.; Whalley, W.R.; Barraclough, P.B. How do roots penetrate strong soil? Plant. Soil 2003, 255, 93-104. [CrossRef]

16. Bengough, A.G.; McKenzie, B.M.; Hallett, P.D.; Valentine, T.A. Root elongation, water stress, and mechanical impedance: A review of limiting stresses and beneficial root tip traits. J. Exp. Bot. 2011, 62, 59-68. [CrossRef]

17. Coll, L.; Camarero, J.J.; Martínez De Aragón, J. Fine root seasonal dynamics, plasticity, and mycorrhization in 2 coexisting Mediterranean oaks with contrasting aboveground phenology. Ecoscience 2012, 19, 238-245. [CrossRef]

18. Germon, A.; Laclau, J.P.; Robin, A.; Jourdan, C. Tamm Review: Deep fine roots in forest ecosystems: Why dig deeper? For. Ecol. Manag. 2020, 466, 118135. [CrossRef] 
19. Kalliokoski, T.; Pennanen, T.; Nygren, P.; Sievanen, R.; Helmisaari, H.S. Belowground interspecific competition in mixed boreal forests: Fine root and ectomycorrhiza characteristics along stand developmental stage and soil fertility gradients. Plant. Soil 2010, 330, 73-89. [CrossRef]

20. Tobner, C.M.; Paquette, A.; Messier, C. Interspecific coordination and intraspecific plasticity of fine root traits in North American temperate tree species. Front. Plant. Sci. 2013, 4, 242. [CrossRef]

21. Reich, P.B.; Tjoelker, M.G.; Walters, M.B.; Vanderklein, D.W.; Buschena, C. Close association of RGR, leaf and root morphology, seed mass and shade tolerance in seedlings of nine boreal tree species grown in high and low light. Funct. Ecol. 1998, 12, 327-338. [CrossRef]

22. Bolte, A.; Villanueva, I. Interspecific competition impacts on the morphology and distribution of fine roots in European beech (Fagus sylvatica L.) and Norway spruce (Picea abies (L.) Karst.). Eur. J. For. Res. 2006, 125, 15-26. [CrossRef]

23. Robertson, G.P.; Coleman, D.C.; Bledsoe, C.S.; Sollins, P. Standard Soil Methods for Long-Term Ecological Research, 1st ed.; Oxford University Press: New York, NY, USA, 1999; pp. 89-166.

24. Mehlich, A. Mehlich 3 soil test extractant: A modification of the Melich 2 extractant. Commun. Soil Plan. 1984, 15, 1409-1416. [CrossRef]

25. Kong, D.L.; Ma, C.E.; Zhang, Q.; Li, L.; Chen, X.; Zeng, H.; Guo, D. Leading dimensions in absorptive root trait variation across 96 subtropical forest species. New Phytol. 2014, 203, 863-872. [CrossRef] [PubMed]

26. Berg, M.P.; Ellers, J. Trait plasticity in species interactions: A driving force of community dynamics. Evol. Ecol. 2010, 24, 617-629. [CrossRef]

27. Kembel, S.W.; Cahill, J.F., Jr. Independent evolution of leaf and root traits within and among temperate grassland plant communities. PLoS ONE 2011, 6, e19992. [CrossRef]

28. Comas, L.; Mueller, K.; Taylor, L.; Midford, P.E.; Callahan, H.S.; Beerling, D.J. Evolutionary patterns and biogeochemical significance of angiosperm root traits. Int. J. Plant. Sci. 2012, 173, 584-595. [CrossRef]

29. Caldwell, M.M.; Manwaring, J.H.; Durham, S.L. Species interactions at the level of fine roots in the field: Influence of soil nutrient heterogeneity and plant size. Oecologia 1996, 106, 440-447. [CrossRef]

30. Bezemer, T.M.; Fountain, M.; Barea, J.M.; Christensen, S.; Dekker, S.C.; Duyts, H.; van Hal, R.; Harvey, J.A.; Hedlund, K.; Maraun, M.; et al. Divergent composition but similar function of soil food webs beneath individual plants: Plant species and community effects. Ecology 2010, 91, 3027-3036. [CrossRef]

31. Phillips, R.P.; Brzostek, E.; Midgley, M.G. The mycorrhizal-associated nutrient economy: A new framework for predicting carbon-nutrient couplings in temperate forests. New Phytol. 2013, 199, 41-51. [CrossRef]

32. Weemstra, M.; Mommer, L.; Visser, E.J.W.; van Ruijven, J.; Kuyper, T.W.; Mohren, G.M.J.; Sterck, F.J. Towards a multidimensional root trait framework: A tree root review. New Phytol. 2016, 211, 1159-1169. [CrossRef] [PubMed]

33. Lambers, H.; John, A.R.; Shaver, G.R.; Smith, S.E. Plant nutrient-acquisition strategies change with soil age. Trends Ecol. Evol. 2008, 23, 95-103. [CrossRef] [PubMed]

34. Brundrett, M.C. Coevolution of roots and mycorrhizas of land plants. New Phytol. 2002, 154, 275-304. [CrossRef]

35. Chen, W.; Koide, R.T.; Adams, T.S.; DeForest, J.L.; Cheng, L.; Eissenstat, D.M. Root morphology and mycorrhizal symbioses together shape nutrient foraging strategies of temperate trees. Proc. Natl. Acad. Sci. USA 2016, 113, 8741-8746. [CrossRef] [PubMed]

36. Bardgett, R.D.; Mommer, L.; De Vries, F.T. Going underground: Root traits as drivers of ecosystem processes. Trends Ecol. Evol. 2014, 29, 692-699. [CrossRef] [PubMed]

37. Sun, J.J. Ectomycorrhizal Colonization Rates of Root Tips of Larix gmelinii, Picea koraiensis and Pinus koraiensis in Pure Plantations and in Mixed Plantations with Fraxinus mandshurica. Master's Thesis, Northeast Forestry University, Harbin, China, 2012. (In Chinese)

38. Bauhus, J.; Khanna, P.K.; Menden, N. Aboveground and belowground interactions in mixed plantations of Eucalyptus globulus and Acacia mearnsii. Can. J. For. Res. 2000, 30, 1886-1894. [CrossRef]

39. Eissenstat, D.M.; Wells, C.E.; Yanai, R.D.; Whitbeck, J.L. Building roots in a changing environment: Implications for root longevity. New Phytol. 2000, 147, 33-42. [CrossRef]

40. McCormack, M.L.; Adams, T.S.; Smithwick, E.A.H.; Eissenstat, D.M. Predicting fine root lifespan from plant functional traits in temperate trees. New Phytol. 2012, 195, 823-831. [CrossRef]

41. Hodge, A.; Berta, G.; Doussan, C.; Merchan, F.; Crespi, M. Plant root growth, architecture and function. Plant. Soil 2009, 321, 153-187. [CrossRef]

42. Montagnoli, A.; Dumroese, R.K.; Terzaghi, M.; Onelli, E.; Gabriella, S.S.; Chiatante, D. Seasonality of fine root dynamics and activity of root and shoot vascular cambium in a Quercus ilex L. forest (Italy). For. Ecol. Manag. 2019, 431, 26-34. [CrossRef]

43. Crang, R.; Lyons-Sobaski, S.; Wise, R. Plant. Anatomy: A Concept-Based Approach to the Structure of Seed Plants, 1st ed.; Springer Nature Switzerland AG: Cham, Switzerland, 2018; pp. 319-353, 479-507.

44. Pierret, A.; Doussan, C.; Capowiez, Y.; Bastardie, F.; Pages, L. Root functional architecture: A framework for modeling the interplay between roots and soil. Vadose Zone J. 2007, 6, 269-281. [CrossRef]

45. Rellán-Álvarez, R.; Lobet, G.; Dinneny, J.R. Environmental control of root system biology. Annu. Rev. Plant. Biol. 2016, 67, 619-642. [CrossRef] [PubMed] 
46. Ostonen, I.; Truu, M.; Helmisaari, H.S.; Lukac, M.; Borken, W.; Vanguelova, E.; Godbold, D.L.; Lõhmus, K.; Zang, U.; Tedersoo, L.; et al. Adaptive root foraging strategies along a boreal-temperate forest gradient. New Phytol. 2017, 215, 977-991. [CrossRef] [PubMed]

47. Meier, I.C.; Brunner, I.; Godbold, D.; Helmisaari, H.M.; Ostonen, I.; Soudzilovskaia, N.A.; Prescott, C.E. Roots and rhizospheres in forest ecosystems: Recent advances and future challenges. For. Ecol. Manag. 2019, 431, 1-5. [CrossRef]

48. Chandra, S.; Singh, A.; Singh, C.P.; Nautiyal, M.C.; Rawat, L.S. Vascular plants distribution in relation to topography and environmental variables in alpine zone of Kedarnath Wild Life Sanctuary, West Himalaya, India. J. Mt. Sci. Engl. 2018, 15, 1936-1949. [CrossRef]

49. Cantarel, A.M.; Pommier, T.; Desclos-Theveniau, M.; Diquélou, S.; Dumont, M.; Grassein, F.; Kastl, E.M.; Grigulis, K.; Lané, P.; Lavorel, S. Using plant traits to explain plant-microbe relationships involved in nitrogen acquisition. Ecology 2015, 96, 788-799. [CrossRef]

50. Zwetsloot, M.J.; Kessler, A.; Bauerle, T.L. Phenolic root exudate and tissue compounds vary widely among temperate forest tree species and have contrasting effects on soil microbial respiration. New Phytol. 2018, 218, 530-541. [CrossRef]

51. Comas, L.H.; Callahan, H.S.; Midford, P.E. Patterns in root traits of woody species hosting arbuscular and ectomycorrhizas: Implications for the evolution of belowground strategies. Ecol. Evol. 2014, 4, 2979-2990. [CrossRef]

52. Valverde-Barrantes, O.J.; Horning, A.L.; Smemo, K.A.; Blackwood, C.B. Phylogenetically structured traits in root systems influence arbuscular mycorrhizal colonization in woody angiosperms. Plant. Soil 2016, 404, 1-12. [CrossRef] 